\title{
AC 2007-3112: IMPLEMENTING ENGINEERING ENTREPRENEURSHIP EDUCATION AT LAFAYETTE COLLEGE
}

Russell Dinardi, Lafayette College

Sharon Jones, Lafayette College 


\section{Implementing Engineering Entrepreneurship Education at Lafayette College}

\section{Introduction}

Entrepreneurship is growing in relation to the fields of technology as well as the economy. As a result, the definition of entrepreneurship is evolving. According to some sources, entrepreneurship is a very broad field and can simply be defined as innovation. ${ }^{1}$ The National Dialogue on Entrepreneurship defines entrepreneurship specifically in terms of the economy and growing a business or venture. ${ }^{2}$ In general, the definition of entrepreneurship varies with people's perceptions. Others define entrepreneurship in terms of the context of their field of study. A more accurate assessment of entrepreneurship for this study may be a more specific definition which encompasses the broad scope of entrepreneurship. The Entrepreneurship Center at Miami University of Ohio defines entrepreneurship as "The process of identifying, developing, and bringing a vision to life. The vision may be an innovative idea, an opportunity, or simply a better way to do something. The end result of this process is the creation of a new venture, formed under conditions of risk and considerable uncertainty."

As the field of entrepreneurship is developed, the differences in the types of emerging entrepreneurs are developing as well. Those entrepreneurs with a specialty in the fields of technology and innovation are forming the backbone for engineering entrepreneurship. With continuing improvements in technology and new innovations being developed almost daily, there arises the need for new businesses and ventures to promote these ideas and products. These businesses and ventures are being founded by individuals with both a technical and analytical background as well as the necessary skills to become an entrepreneur. This field of engineering entrepreneurship is becoming increasingly important as motivated individuals are changing society with their new and improved innovations.

The economic trend of growth is currently shifting towards the emergence of entrepreneurships. The Economist states that, "America gets more than half of its economic growth from industries that barely existed a decade ago...."3 Technical innovations are leading the way for this economic growth, making it more important that engineers understand the fundamentals underlying entrepreneurship so that they have an advantage in the field of engineering entrepreneurship. "A technological professional with entrepreneurial skills has a better chance than a business administrator of moving innovations from research into manufacturing and the marketplace."4

\section{Significance of Study}

The purpose of this study is to examine the existing literature in the field of entrepreneurship as well as the need within Lafayette College for an entrepreneurship program. Through the study of existing entrepreneurship 
literature, the benefits of an entrepreneurship program within Lafayette College's engineering department will become clear. The study will also provide the background and framework for later studies into the implementation of an entrepreneurship program at Lafayette. In order to facilitate later implementation of an entrepreneurship program, some tools and techniques that should be considered for Lafayette College have been made in the conclusion of the paper.

At the moment, no entrepreneurship programs exist in any departments at Lafayette College. The only form of entrepreneurship education is the Circle Entrepreneurship Society, which offers economics and business students the opportunity to gather and speak about entrepreneurial topics. In addition, the society occasionally invites speakers to their meetings. For students outside of the economics and business field, little opportunity for entrepreneurship education exists. Already with a solid technological background, Lafayette's engineering students can have very successful careers in fields involving technical innovation. Lafayette engineering students are not fully aware of the possibilities that lie within the field of entrepreneurship because there are currently such few opportunities on campus. Entrepreneurship education is growing across the United States with a focus on students learning about the competencies of successful entrepreneurs. "More than 2000 colleges and universities in the United States, about two-thirds of the total, now offer a course in entrepreneurship." Advocates of such education argue that these competencies will not only help in the field of entrepreneurship, but they are skills and traits which will give individuals an advantage in all of their endeavors. The rest of this paper will examine the literature concerning entrepreneurship and entrepreneurship education, the importance of entrepreneurship education at similar colleges and universities, and the need for entrepreneurship education to be made available to Lafayette College engineering students.

\section{Overview of Lafayette College and its Engineering Division}

Lafayette College is an undergraduate liberal arts institution with an enrollment of 2,381 students. The college offers 46 areas of study across four divisions: natural sciences, engineering, humanities and social sciences. The Engineering Division offers six degrees in engineering (A.B. Engineering, Chemical Engineering, Civil and Environmental Engineering, Electrical and Computer Engineering, International Studies and Engineering, Mechanical Engineering), all providing a first-rate engineering education in an environment that features close interaction between students and faculty. As an engineering student at Lafayette College, there is an added dimension to the education. Engineering students at the college study liberal arts in addition to the technical courses required. The expectation is that Lafayette's engineers have a better sense of the social, political, ethical, economic, and environmental consequences of technology. Due to the strict requirements of ABET accreditation, the intended values of a liberal arts education are not always instilled in the courses within the engineering curriculum. Extending its education beyond coursework, the college prides itself as a national leader in self-directed 
intensive research with faculty monitoring. Upon graduation, Lafayette's engineering students occupy leadership positions in many of the nation's top technological companies, including Air Products \& Chemicals, Foster Wheeler, DuPont, AT\&T, Ingersoll-Rand, General Electric, Xerox and Merck \& Co., Inc. ${ }^{6}$

\section{History of Entrepreneurship}

While the term entrepreneurship carries with it a diversity of meanings and is only currently being formalized as a field of study, its history originates in France in the early $18^{\text {th }}$ century. Richard Cantillon in 1725 took the term entrepreneur, French for "risk taking," and separated the activities of entrepreneurs from capitalist activities. Adam Smith, later in the $18^{\text {th }}$ century, described the activities of the entrepreneur in The Wealth of Nations, yet he attributed them to the capitalist. ${ }^{8}$ Jean-Baptiste Say, in the early part of the $19^{\text {th }}$ century, defined the term "entrepreneur" to mean improving the state of resources used in production. ${ }^{9}$ The next development in entrepreneurship occurred in 1871, when John Stuart Mill associated the risk taking of entrepreneurs with the risks of capitalists in seeking profits, but assumed that these were one activity and a collective risk. ${ }^{10}$ Possibly the largest impact in the field of entrepreneurship came in 1934 when Joseph Schumpeter defined entrepreneurs as separate from capitalists and incorporated innovation into the role of entrepreneurs. ${ }^{11}$ As the field of study was progressing and in the absence of entrepreneurship education, entrepreneurs of the past, such as Edison, Carnegie, and others, gained education in entrepreneurship from informal communities of teachers and students in the early industrial cities. These great entrepreneurs used the informal communities to acquire contacts for both skills and resources which they utilized in their successes. ${ }^{12}$ The concept of entrepreneurship is rather new among higher education and is evolving into a formal field of study. Schools are beginning to adopt entrepreneurship into their educational curricula in order to meet the needs of students who are seeking flexibility in their studies as they realize that their careers will not be spent in one job, or with one company.

\section{Technological Entrepreneurship}

One of the emerging fields within the broad spectrum of entrepreneurship is technological or engineering entrepreneurship. Currently, the economy is at a crossroads of competitive globalization and the creative economy. ${ }^{13}$ The amount of information becoming available to the average person has been increasing as technological advancements have made access to this information more convenient. As the information exchange rate has been steadily increasing, so too has the reliance of the United States economy on the global economy. These factors have led to the need for individuals and businesses which can translate science and technology into easily understandable information. ${ }^{14}$ This necessity for technological entrepreneurship requires individuals who are both able to ensure the functionality and reliability of the emerging technology as well as being able to market and sell the product for a profit.

Research showing the high-growth rate of certain industries also indicates that the industries within technological entrepreneurship offer better opportunities for 
founding new companies. In a study by Jon Eckhardt, relating Inc. 500 companies and the percentage of start-up companies listed on the Inc. 500, he found that certain industries provided a better chance for developing new companies. ${ }^{15}$ Among the top ten industries with a high percentage of start-ups as Inc. 500 firms were pulp mills, computer and office equipment, guided missiles, space vehicles, and parts, nonferrous rolling and drawing, measuring and controlling devices, paper mills, search and navigation equipment, communications equipment, and drugs. ${ }^{16}$ The number of industries with a high growth rate that are utilizing technological innovation indicates the need for an emphasis on technology in the field of entrepreneurship.

\section{Economic Impacts of Entrepreneurship in the United States}

While students have been drawn to the field of entrepreneurship for the potential success it offers their careers, there is also a growing need in the economy for entrepreneurship education. Economic trends in the United States indicate a shift to an entrepreneurial economy. These trends have been influenced by policy actions of the government over the past thirty years in order to promote entrepreneurial activity. Policy initiatives which have supported this entrepreneurial shift include: ${ }^{17}$

1. The removal of legal barriers to entry and price controls in a number of key industries, in particular, transportation and communication

2. Successive executive orders requiring executive branch agencies to at least study the costs and benefits of introducing new regulations before adopting them, and legislation requiring agencies to tailor their regulations to "the size and the resources of the affected business" (with special regulatory flexibility for small businesses seeking to raise capital)

3. Various tax reforms that have had the effect of enhancing the rewards from entrepreneurship, including cuts in the capital gains tax rate and reductions in the top individual marginal tax rate

4. Legal changes that have allowed pension funds to finance the formation and growth of new firms by investing in venture capital partnerships

5. Federal legislation aimed at accelerating the commercialization of innovations in universities and small businesses

The United States has shown an ability to foster entrepreneurship. From 2004 to 2005, the ratio of early-stage entrepreneurship to established business ownership grew from 2.0 entrepreneurs per established business owner to 2.6 entrepreneurs per established business owner. ${ }^{18}$ Most of this entrepreneurial activity is driven by the motivation of new market activity, or opportunity entrepreneurial activity, as can be seen in Figure 1. ${ }^{19}$ Also, entrepreneurship accounts for the annual creation of 600,000 to 800,000 new companies, which results in the creation of many new jobs in the economy. ${ }^{20}$ The strength of the American entrepreneurial culture is evident in 
the persistently high levels of entrepreneurial activity as well as in the low impact of national economic factors on entrepreneurship levels. ${ }^{21}$

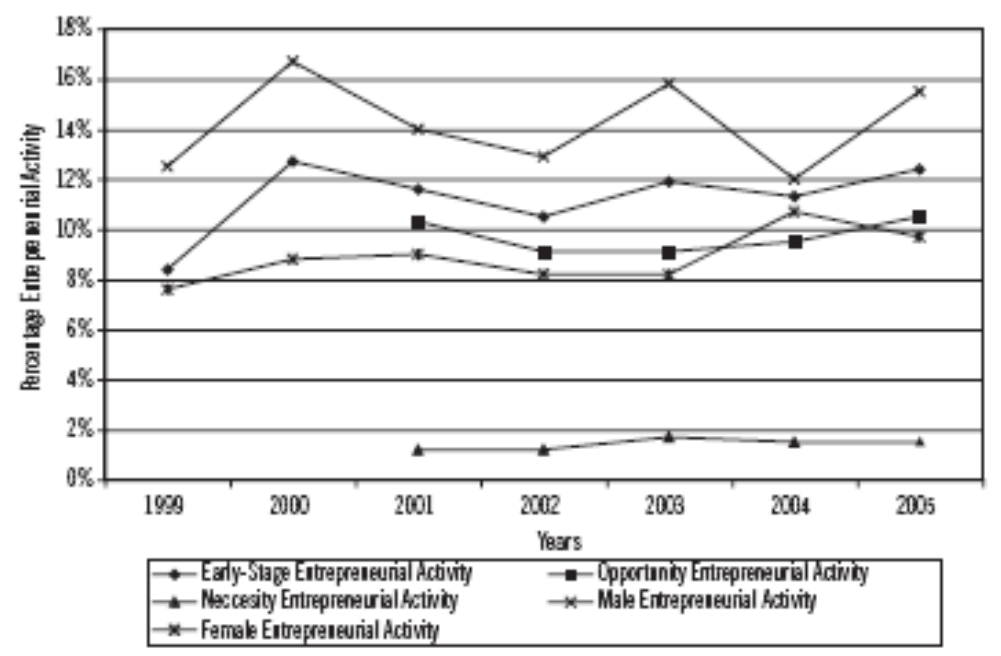

Figure 1. US Entrepreneurial Trends ${ }^{22}$

\section{Trends in Entrepreneurship}

The increase in entrepreneurial activity can be seen in the increasing amount of research being done in the field of entrepreneurship. Entrepreneurship is an evolving field with a relative lack of research in its past. Institutions are beginning to formalize the education of this field, yet little research has been done concerning the effects of this education on the students who pursue this field of study. "More than 1000 publications now appear annually in the field of entrepreneurship, at more than 50 conferences and in 25 specialized journals." 23 In addition, the formalization of entrepreneurship education indicates an increase in entrepreneurial activity. The number of endowed professors in entrepreneurialism has shown a seventy-one percent increase in US colleges and universities from 1999 through 2003, with an increase from 237 professorships to $406 .{ }^{24}$ Also, the vast majority of the first doctoral graduates in entrepreneurship in the 1980s were from fields other than entrepreneurship, and it was not their main field of study. ${ }^{25}$ Currently, foundations and organizations such as the Ewing Marion Kauffman Foundation and the National Collegiate Inventors and Innovators Alliance provide grants to schools demonstrating intent to provide entrepreneurship education, with a recent initiative by the Kauffman Foundation to promote multidisciplinary entrepreneurship education among colleges and universities beginning in 2003 with eight colleges and universities receiving $\$ 25$ million in grants.

Individual Contributions to Entrepreneurship 
American entrepreneurship has been shaped by the efforts of individuals, through whom the modern concept of entrepreneurship has been established. Two individuals who are credited with contributing to the American entrepreneurship movement are Tom Peters and Peter Drucker. While the ideas developed by Peters and Drucker did not directly correlate to entrepreneurship, they helped to redefine society's view of business and spur the study of the field of entrepreneurship.

Tom Peters began as a consultant for McKinsey and Company before venturing out as an independent consultant. It was his work In Search of Excellence that inspired entrepreneurs, though. In this work, Peters promoted the ideas of empowering decision makers at all levels of an organization. He believed that action was more important than theorizing and developing ideas. According to Percy Barnevik, an adherent to the advice of Peters, "Ideas and strategies are important, of course, but execution is the real challenge." 26 In addition, Tom Peters expressed further keys to success as networking with anyone who could help out a business, acting upon the moment, and being open to different perspectives. ${ }^{27}$ These ideas, revolutionary to their time, helped to construct the framework for the modern concept of entrepreneurship.

Peter Drucker is another individual who made prominent contributions to the modern framework of entrepreneurship. Drucker was an Austrian-born management specialist who became fascinated with the structure and managerial techniques of General Motors. He developed radical theories concerning the functions of managers. Drucker's view of management was detailed in The Practice of Management. He felt that their overall objective was to give vision and the ability to perform. He also developed the theory of management by objectives, in which the job of a manager should be focused around the performance of a certain objective and not around the critique of their boss. In addition to redefining the practices of managers, he redefined the term manager in Managing in a Time of Great Change in which he claimed that the term manager should imply responsibility as opposed to power. ${ }^{28}$ These ideas helped to revolutionize the corporate leadership roles for all industries.

\section{Characteristics of Entrepreneurs}

Entrepreneurship is defined differently by people depending upon their viewpoint or field of study. Researchers and scholars tend to define entrepreneurs specifically to their disciplines. Economists introduce the idea of innovation into entrepreneurship, yet they have trouble in describing entrepreneurial behavior rationally. ${ }^{29}$ Behaviorists on the other hand define entrepreneurs according to the characteristics attributed to them. ${ }^{30}$

The characteristics of most entrepreneurs cannot be defined as a specific and unyielding set of traits, but rather they share some common attributes which are reflected in the actions and decisions of successful entrepreneurs. While entrepreneurs may share in these common characteristics, there is no consensus 
among researchers as to the characteristics of entrepreneurs. Caron St. John, the Director of the entrepreneurial center at Clemson University, refers to these attributes as personality, perspective, and context. Some of these personality traits are confidence, intelligence, creativity, willingness to take initiative and responsibility, ability to influence others, and willingness to take calculated risks. ${ }^{31}$ Figure 2 demonstrates how the personality attributes of entrepreneurs relate to entrepreneurial perspectives. William Pendergast, a professor of business at California State Polytechnic Institute, recognizes similar attributes in entrepreneurs describing them as contexts and traits. As he describes it, "The distinctive quality of the early-stage entrepreneurial experience arises from its focus on opportunity, uncertainty and lack of structure, resource scarcity, and fluid or dynamic quality., ${ }^{2}$ He also recognizes entrepreneurs as possessing traits which are specific to the entrepreneurial experience which he describes and can be seen in Figure 3.

\begin{tabular}{|l|l|l|}
\hline & $\begin{array}{l}\text { Entrepreneur } \\
\text { Perspective }\end{array}$ & $\begin{array}{l}\text { Entrepreneur } \\
\text { Attribute }\end{array}$ \\
\hline Driven by & $\begin{array}{l}\text { Perception of } \\
\text { opportunity }\end{array}$ & $\begin{array}{l}\text { Entrepreneurial } \\
\text { insight, what "can be" } \\
\text { in future }\end{array}$ \\
\hline $\begin{array}{l}\text { Commitment to } \\
\text { Opportunity }\end{array}$ & $\begin{array}{l}\text { Fast reaction, short } \\
\text { term }\end{array}$ & Tolerate uncertainty \\
\hline $\begin{array}{l}\text { Management of } \\
\text { Resources }\end{array}$ & $\begin{array}{l}\text { Staged allocation, } \\
\text { minimal exposure }\end{array}$ & $\begin{array}{l}\text { Build relationships } \\
\text { with other resource } \\
\text { holders }\end{array}$ \\
\hline $\begin{array}{l}\text { Structure and } \\
\text { Rewards }\end{array}$ & $\begin{array}{l}\text { Flat organization, use } \\
\text { of networks, } \\
\text { individual rewards }\end{array}$ & $\begin{array}{l}\text { Identify and motivate } \\
\text { highly skilled team }\end{array}$ \\
\hline
\end{tabular}

Figure 2. Perspectives and Attributes ${ }^{33}$ 


\begin{tabular}{|l|l|}
\hline $\begin{array}{l}\text { THE ENTREPRENEURIAL } \\
\text { EXPERIENCE }\end{array}$ & TRAITS OF ENTREPRENEURS \\
\hline Opportunity focused & $\begin{array}{l}\text { Inquisitiveness, opportunity-recognition } \\
\text { Action-orientation (pro-active) } \\
\text { Need for achievement }\end{array}$ \\
\hline Unstructured, uncertain & $\begin{array}{l}\text { Tolerance of ambiguity, uncertainty } \\
\text { Independence, self-starting, internal locus } \\
\text { of control, individualism } \\
\text { Risk propensity } \\
\text { Creativity, innovative }\end{array}$ \\
\hline Scarce resources & $\begin{array}{l}\text { Networking, coalition building } \\
\text { Teamwork, hero-making }\end{array}$ \\
& $\begin{array}{l}\text { Belief in personal efficacy } \\
\text { Niche-craft }\end{array}$ \\
& Persistence, determination \\
\hline Dynamic, turbulent, fluid & $\begin{array}{l}\text { Improvisation } \\
\text { Empirical, pragmatic experimental, } \\
\end{array}$ \\
& Muddle through \\
\hline
\end{tabular}

Figure 3. Entrepreneurial Traits Related to the Entrepreneurial Experience ${ }^{34}$

Similar characteristics and traits appear in the study of entrepreneurs by other researchers. Bruce McDaniel notes the characteristics of an entrepreneur to include self-esteem, persistence, willingness and ability to take calculated risks, creativity, and responsibility/ability to accept control. ${ }^{35}$ Daniel Hjorth points out that an entrepreneur has high managerial skills and business know-how, but what separates the entrepreneur from the manager are the high levels of creativity and innovation. ${ }^{36}$ There are many characteristics and behaviors which can be associated with entrepreneurs and attempting to focus on and teach all of them would be unproductive. For that reason, this study will focus on the competencies which can be taught to instill the characteristics of entrepreneurs in students. Comparing the entrepreneurial characteristics suggested by the researchers, there is a common thread of leadership, critical and creative thinking, and communication skills among entrepreneurs under a context of risk and uncertainty. In addition, an underlying theme throughout entrepreneurship is the ability to recognize and evaluate business opportunities and to adjust as opportunities arise; therefore, this study will also focus on the competencies of business savvy and flexibility/adaptability.

\section{Methodology}

In examining the various methods by which Lafayette College can incorporate entrepreneurship education in its Engineering Division, it is useful to benchmark institutions with successful entrepreneurial programs. In the benchmarking, my focus was to identify how each school meets the five competencies that I summarized in the previous section. While many colleges and universities have agreed upon the need to incorporate entrepreneurship education in their curricula, they have differed in their methods and subject matter concerning entrepreneurial studies. In order to explore the methods employed by similar institutions, I selected a sample of schools which are comparable to Lafayette College from the US New and World Report rankings of undergraduate engineering programs without a $\mathrm{PhD}$ 
program. Lehigh University was selected for its geographic proximity to Lafayette College. While some of the more successful entrepreneurship programs have been implemented at public universities, I excluded public universities because they are too large and have too many more resources available to compare for Lafayette College. Below is a comparison of similar institutions with entrepreneurial programs.

\begin{tabular}{|c|c|c|c|c|c|c|c|}
\hline Schools & $\begin{array}{c}\text { Lafayette } \\
\text { College }\end{array}$ & $\begin{array}{c}\text { Baylor } \\
\text { University }\end{array}$ & $\begin{array}{c}\text { Loyola } \\
\text { Marymount } \\
\text { University }\end{array}$ & $\begin{array}{c}\text { Texas } \\
\text { Christian } \\
\text { University }\end{array}$ & $\begin{array}{c}\text { Fairleigh } \\
\text { Dickinson } \\
\text { University }\end{array}$ & $\begin{array}{c}\text { Gonzaga } \\
\text { University }\end{array}$ & $\begin{array}{c}\text { Lehigh } \\
\text { University }\end{array}$ \\
\hline $\begin{array}{c}\text { Total } \\
\text { Undergrad } \\
\text { Population }\end{array}$ & 2,381 & 11,831 & 5,341 & 6,857 & 6,514 & 4,150 & 4,679 \\
\hline $\begin{array}{c}\text { Undergrad } \\
\text { Engineering } \\
\text { Population }\end{array}$ & 495 & 538 & 268 & 141 & N/A & 427 & 1,554 \\
\hline $\begin{array}{c}\text { Location } \\
\text { (as } \\
\text { classified } \\
\text { by ASEE) }\end{array}$ & $\begin{array}{c}\text { Urban: } \\
\text { Easton, } \\
\text { PA }\end{array}$ & Wraco, TX & $\begin{array}{c}\text { Suburban: } \\
\text { Los Angeles, } \\
\text { CA }\end{array}$ & $\begin{array}{c}\text { Urban: Fort } \\
\text { Worth, TX }\end{array}$ & $\begin{array}{c}\text { Teaneck, } \\
\text { NJ } \\
\text { NNot } \\
\text { Reported }\end{array}$ & $\begin{array}{c}\text { Urban: } \\
\text { Spokane, } \\
\text { WA }\end{array}$ & $\begin{array}{c}\text { Small } \\
\text { Town: } \\
\text { Bethlehem, } \\
\text { PA }\end{array}$ \\
\hline $\begin{array}{c}\text { Founded } \\
\text { Undergrad }\end{array}$ & 1826 & 1845 & 1911 & 1873 & 1942 & 1887 & 1865 \\
$\begin{array}{c}\text { Student to } \\
\text { Faculty } \\
\text { Ratio }\end{array}$ & $11: 1$ & $16: 1$ & $14: 1$ & $15: 1$ & $14: 1$ & $12: 1$ & $9: 1$ \\
\hline $\begin{array}{c}\text { US News } \\
\text { and World } \\
\text { Report } \\
\text { Engineering } \\
\text { Ranking } \\
\text { (2005) }\end{array}$ & 10 & 14 & 19 & 39 & 54 & 21 & N/A \\
\hline $\begin{array}{c}\text { US News } \\
\text { and World } \\
\text { Report }\end{array}$ & 30 & N/A & N/A & N/A & N/A & N/A & N/A \\
$\begin{array}{c}\text { Liberal Arts } \\
\text { Rankings } \\
\text { (2007) }\end{array}$ & & & 1,997 & 610 & 3,550 & 2,225 & 2,069 \\
\hline $\begin{array}{c}\text { Graduate } \\
\text { Student } \\
\text { Population }\end{array}$ & N/A & 1,278 & private & private & private & private & private \\
\hline $\begin{array}{c}\text { Type of } \\
\text { Institution }\end{array}$ & private & private & & & & & \\
\hline
\end{tabular}

\section{Benchmarking}

As can be seen in the methods of teaching entrepreneurial competencies below, each institution utilizes different tactics in their educational approach. Some of the 
overriding themes found throughout the teaching methods are the existence of mentoring relationships with individuals in the business world, the use of entrepreneurial internships to help students gain experience beyond the classroom, the presence of entrepreneurial societies or clubs, the importance of business knowledge, and learning from the advice of practicing entrepreneurs. In addition, each school uses different methods of teaching creative thinking. This competency is one which is difficult to teach in traditional curricula.

\section{Baylor University:}

- Through the entrepreneurship program at Baylor University, students are able to take a hands-on approach to learning entrepreneurship.

- Through the Venture Assistance Program, student help with pre-venture planning, start-up problems, consulting on operation problems, product and business expansions, and terminations and bankruptcies. This also gives students industry experience and contacts for the future.

- Through the courses and design courses at Baylor, students develop solutions to problems under conditions of risk and ambiguity. They also learn how to manufacture new products and market them. Students have obtained licensing agreements for products they developed marketing and business plans for during course work.

- Courses are taught by faculty, visiting faculty, and guest lecturers. The program is continuously evaluated and adjusted to meet the needs of the students. The program is also set up for expansion and with less structure and fewer constraints than other curricula.

\section{Loyola Marymount University:}

- The entrepreneurship program at Loyola Marymount infuses real-world experiences into classroom learning. Students are able to perform internships and use the knowledge gained from these experiences in their entrepreneurial studies.

- The students are first required to take business courses as a prerequisite to the entrepreneurship program in order to develop an analytical background. The business fundamentals also help in the entrepreneurship courses where students are required to develop business plans. The entrepreneurship program also attempts to teach students big business environments while also learning how to start and grow a business venture.

- Much of the grading for the entrepreneurship program is based on projects, presentations, and teamwork. Students are encouraged to perform career 
self-assessments and get to know their abilities through courses and projects in entrepreneurship.

\section{Texas Christian University:}

- The entrepreneurship program at Texas Christian requires its students to learn outside of the classroom as well as through coursework. Students are encouraged in the program to contact entrepreneurs and interview them through their own initiative, or a "learn=by-doing" approach.

- Students are provided with resources, such as reading materials on industries, in order to be proactive in their learning. They are also encouraged to try their hand at building a start-up as a student. Start-ups at Texas Christian have been successful in the past, such as newspapers, landscaping businesses, and web development companies. This also requires students to learn time management skills and set goals for themselves.

- Through internships and mentoring relationships, students are able to gain experience beyond the classroom in entrepreneurship. Students are also encouraged to contact entrepreneurs in order to begin learning to network. CEO (Collegiate Entrepreneurs Organization) is available to help students with this task.

\section{Fairleigh Dickinson University:}

- The entrepreneurship program at Fairleigh Dickinson offers an opportunity for students to personalize their entrepreneurship education.

- The entrepreneurship program offers a variety of courses to accommodate for the needs of many students. Courses such as Entrepreneurship for the Arts, Sciences, Sports, and Technology and Family Business Management allow students to utilize entrepreneurship education to meet their personal interests.

- Special Projects in Entrepreneurship offers an independent study with realworld applications for entrepreneurship education.

- A Guided Study in Entrepreneurial Studies allows students to design projects which will enhance their personal career goals.

- Courses also fuse business studies with entrepreneurship, such as Small Business Management, Finance in an Entrepreneurial Environment, and Advanced Business Planning. 
- Internships and mentoring relationships also provide students with an opportunity to learn from experiences outside of the classroom.

\section{Gonzaga University:}

- The Hogan Entrepreneurial Leadership program offers entrepreneurship education with an emphasis on leadership. Students must first demonstrate leadership qualities and apply for acceptance into this entrepreneurship program. These qualities are further developed through courses such as Entrepreneurial Leadership and Stressing Ethical Leadership for the Common Good.

- Students complete their degree in Business, Engineering, Arts and Sciences, or Education in addition to taking entrepreneurship courses.

- Through the entrepreneurship program, students are offered a variety of independent study projects. The New Venture Lab allows students to develop business plans and models for a new business and requires students to apply the concepts of entrepreneurship to their models. The Incubation Project allows students a similar experience in creating new ventures with fundable business plans through the application of entrepreneurial concepts and analytical tools. Students may also participate in Business plan competitions.

- Internships and mentoring relationships also provide students with an opportunity to learn from experiences outside of the classroom.

\section{Lehigh University:}

- The entrepreneurship minor at Lehigh allows students to recognize and apply entrepreneurial concepts to other disciplines which students are majoring in.

- Through coursework, students learn to review business plans, market and business life-cycles, ethical, technical, and managerial challenges of creating new ventures, and the role of technological innovation.

- The "learn-by-doing" environment is stressed as students are encouraged to develop business plans and compete in business plan competitions, such as The Lehigh University Student Entrepreneurs Competition that is open to all teams with at least one member enrolled at Lehigh. 


\begin{tabular}{|c|c|c|c|c|c|}
\hline Schools & $\begin{array}{c}\text { Available } \\
\text { Entrepreneurship } \\
\text { Courses }\end{array}$ & $\begin{array}{c}\text { Required } \\
\text { Business } \\
\text { Courses }\end{array}$ & $\begin{array}{c}\text { Mentoring } \\
\text { Programs }\end{array}$ & $\begin{array}{c}\text { Entrepreneurship } \\
\text { Internships }\end{array}$ & $\begin{array}{c}\text { Entrepreneurship } \\
\text { Society or Club }\end{array}$ \\
\hline Baylor & 8 & $\begin{array}{c}\text { Business } \\
\text { Major Core } \\
\text { courses }\end{array}$ & No & Yes & No \\
\hline $\begin{array}{c}\text { Loyola } \\
\text { Marymount }\end{array}$ & 15 & $\begin{array}{c}\text { Business } \\
\text { Major Core } \\
\text { courses }\end{array}$ & No & Yes & Yes \\
\hline $\begin{array}{c}\text { Texas } \\
\text { Christian }\end{array}$ & 9 & $\begin{array}{c}\text { Business } \\
\text { Major Core } \\
\text { courses }\end{array}$ & Yes & Yes & No \\
\hline $\begin{array}{c}\text { Fairleigh } \\
\text { Dickinson }\end{array}$ & 13 & $\begin{array}{c}4(8 \text { for } \\
\text { Business } \\
\text { Management } \\
\text { Concentration })\end{array}$ & Yes & Yes & Yes \\
\hline Gonzaga & 12 & 5 & Yes & Yes & No \\
\hline Lehigh & N/A & $\begin{array}{c}\text { Business } \\
\text { Major Core } \\
\text { courses }\end{array}$ & No & No & Yes \\
\hline Lafayette & N/A & N/A & N/A & N/A & Yes \\
\hline
\end{tabular}

Summary of Methods through which Skills are Attained

\section{Leadership}

\begin{tabular}{|l|l|l|}
\hline Baylor University & $\begin{array}{l}\text { Loyola Marymount } \\
\text { University }\end{array}$ & $\begin{array}{l}\text { Texas Christian } \\
\text { University }\end{array}$ \\
\hline - Venture Assistance Program: & - Course readings & - Courses \\
- Learn in hands-on environment & - Internships & - Internships \\
- Develop experience in industry & - Career self-assessment & - Mentor relationships \\
- Develop contacts & - Business networking & \multicolumn{1}{|c|}{ business world } \\
\hline Fairleigh Dickinson University & Gonzaga University & Lehigh University \\
\hline - Entrepreneurial society & - Hogan Entrepreneurial & - Student \\
- Internships & Leadership Program & Entrepreneurs \\
- Mentor relationships & - Internships & Competition \\
& - Mentor relationships in & - Visiting \\
& - business world & Entrepreneur \\
& - Courses & Lectures \\
& & - Entrepreneurial Club \\
\hline
\end{tabular}




\section{Critical Thinking}

\begin{tabular}{|l|l|l|}
\hline Baylor University & $\begin{array}{l}\text { Loyola Marymount } \\
\text { University }\end{array}$ & $\begin{array}{l}\text { Texas Christian } \\
\text { University }\end{array}$ \\
\hline - Venture Assistance Program & - Business Courses & \\
\hline Fairleigh Dickinson University & Gonzaga University & Lehigh University \\
\hline & $\begin{array}{l}\text { - Complete a degree in } \\
\text { business, engineering, arts } \\
\text { and sciences, or education } \\
\text { - Core curricula }\end{array}$ & $\begin{array}{l}\text { - Review business } \\
\text { plans } \\
\text { - Courses }\end{array}$ \\
& \multicolumn{2}{|l}{} \\
\hline
\end{tabular}

\section{Creative Thinking}

\begin{tabular}{|l|l|l|}
\hline Baylor University & $\begin{array}{l}\text { Loyola Marymount } \\
\text { University }\end{array}$ & $\begin{array}{l}\text { Texas Christian } \\
\text { University }\end{array}$ \\
\hline $\begin{array}{l}\text { - Internships } \\
\text { - Marketing and manufacturing } \\
\text { new products }\end{array}$ & - Develop business plans & $\begin{array}{l}\text { - Provide resources } \\
\text { and tools for } \\
\text { independent learning }\end{array}$ \\
\hline Fairleigh Dickinson University & Gonzaga University & Lehigh University \\
\hline $\begin{array}{l}\text { - Courses: Entrepreneurship for } \\
\text { the Arts, Sciences, Sports, and } \\
\text { Technology }\end{array}$ & $\begin{array}{l}\text { - Business Plan } \\
\text { competitions }\end{array}$ & $\begin{array}{l}\text { Business plan } \\
\text { competitions }\end{array}$ \\
- Special Projects in & - New Venture Lab \\
Entrepreneurship Course & - Incubation Project & \begin{tabular}{l} 
environment \\
\hline
\end{tabular} \\
\hline
\end{tabular}

\section{Business Savvy}

\begin{tabular}{|l|l|l|}
\hline Baylor University & $\begin{array}{l}\text { Loyola Marymount } \\
\text { University }\end{array}$ & $\begin{array}{l}\text { Texas Christian } \\
\text { University }\end{array}$ \\
\hline - Internships & - Business fundamentals & - Mentor relationships \\
- Evaluate opportunities and & courses & \\
- Denduct market analyses & - Internships & \\
\hline Fairleigh Dickinson University & - Business networking & \\
\hline - Courses & Gonzaga University & Lehigh University \\
& $\begin{array}{l}\text { - Major in business } \\
\text { - Foundation in economics } \\
\text { and accounting }\end{array}$ & \\
& $\begin{array}{l}\text { New Venture Creation } \\
\text { course }\end{array}$ & \\
& & \\
\hline
\end{tabular}




\section{Flexibility/Adaptability of Program}

\begin{tabular}{|l|l|l|}
\hline Baylor University & $\begin{array}{l}\text { Loyola Marymount } \\
\text { University }\end{array}$ & $\begin{array}{l}\text { Texas Christian } \\
\text { University }\end{array}$ \\
\hline $\begin{array}{l}\text { - Continuous evaluation and } \\
\text { adjustments of courses }\end{array}$ & $\begin{array}{l}\text { - Grading focused around } \\
\text { projects, presentations, and } \\
\text { - Not overly structured curricula } \\
\text { - Expanding program }\end{array}$ & $\begin{array}{l}\text { - Time Management } \\
\text { skills training and } \\
\text { goal setting } \\
\text { Encourage study } \\
\text { abroad }\end{array}$ \\
\hline Fairleigh Dickinson University & Gonzaga University & Lehigh University \\
\hline $\begin{array}{l}\text { - Range of courses so students can } \\
\text { focus on personal interests }\end{array}$ & $\begin{array}{l}\text { - Diversity of majors and } \\
\text { choice of entrepreneurial } \\
\text { - Design projects to enhance } \\
\text { personal career goals }\end{array}$ & $\begin{array}{l}\text { Entrepreneurship } \\
\text { minor }\end{array}$ \\
- Courses & $\begin{array}{l}\text { Variety of independent } \\
\text { projects }\end{array}$ & \\
\hline
\end{tabular}

\section{Communication}

\begin{tabular}{|c|c|c|}
\hline Baylor University & Loyola Marymount University & $\begin{array}{l}\text { Texas Christian } \\
\text { University }\end{array}$ \\
\hline $\begin{array}{l}\text { Teaching by resident faculty, } \\
\text { visiting faculty, practicing } \\
\text { professionals, and successful } \\
\text { entrepreneurs } \\
\text { - Frequent lectures from } \\
\text { successful entrepreneurs }\end{array}$ & $\begin{array}{l}\text { - Entrepreneurship society } \\
\text { - Powerful speakers } \\
\text { - Networking }\end{array}$ & $\begin{array}{l}\text { - Networking and } \\
\text { interviewing } \\
\text { entrepreneurs } \\
\text { - "Learn by doing" } \\
\text { approach }\end{array}$ \\
\hline $\begin{array}{l}\text { Fairleigh Dickinson } \\
\text { University }\end{array}$ & Gonzaga University & Lehigh University \\
\hline $\begin{array}{l}\text { Interaction with professors } \\
\text { and guest lecturers } \\
\text { - Developing business plans } \\
\text { and implementation planning }\end{array}$ & $\begin{array}{l}\text { - Lectures } \\
\text { - Mentor relationships } \\
\text { - Independent study courses }\end{array}$ & - Entrepreneurial Club \\
\hline
\end{tabular}

\section{Conclusion}

Lafayette College would benefit from the incorporation of an entrepreneurship program within its engineering division by providing a variety of opportunities to instill core competencies as is done at comparable institutions. The trends in the growth of entrepreneurship in the United States economy, especially involving technological innovations, indicate a need for education in the field of entrepreneurship. In this study, it was seen that entrepreneurship programs offer a variety of flexible and adaptive methods of teaching leadership, critical and creative thinking, business savvy, and communication skills. Through the use of these examples, it is seen that students of Lafayette's engineering programs can gain much needed skills from an entrepreneurship program, which attempts to instill these core competencies in the education of its students. While the program will take a few years and some additional 
resources to fully build and develop, the result will be highly beneficial to the students, as they will have a competitive advantage in entrepreneurship and whichever field they choose to pursue.

In order to incorporate entrepreneurship education in the curriculum of the Engineering Division, the college must address the needs of interested students while complying with certain constraints. Lafayette College is a small school with limited resources. Much of the funding for the college emanates from alumni donations. In addition, Lafayette is not located near a prosperous urban area, and there is limited or no access available to technological centers. Also, while the engineering curricula would require changes to incorporate entrepreneurship education, the curricula must still meet ABET requirements. With these conditions in mind, the following are tools and techniques which Lafayette College's Engineering Division might be able to use in incorporating entrepreneurship education which will be beneficial to Lafayette College's engineering students.

- Establishment of Entrepreneurship discipline within the Engineering Division: The establishment of an Entrepreneurship discipline within the Engineering Division would bring in faculty dedicated solely to entrepreneurial studies. In addition to teaching courses on entrepreneurship, the faculty would help in resolving issues with the school concerning proprietary information, patent rights, and intellectual property. The faculty would also search for ways of obtaining venture capital, such as through entrepreneurship foundations.

- Mentor Relationships: Many institutions have successfully developed mentoring programs with executives and practicing entrepreneurs. Through the use of Career Services and alumni networking, alumni of Lafayette College who have entered the field of entrepreneurship could be found and could act as mentors to students interested in entrepreneurship. Two of Lafayette's most benevolent alumni, Hal Kamine '78 and James Fisher '77, have earned their success through entrepreneurial ventures.

- Internships: With the aid of Career Services, an internship program could be established for interested entrepreneurial students. Through the program, students could earn course credit while gaining experience with start-up ventures or newly founded firms.

- Courses teaching entrepreneurship fundamentals: One of the keys to teaching engineering students about entrepreneurship would be through coursework stressing the fundamentals of entrepreneurship. While Lafayette College's Engineering Curricula claim an integration of liberal arts and engineering courses, there are relatively few liberal arts courses taken by the engineering students. Some typical stereotypes of engineers are that they are reactive, have a low tolerance of ambiguity, and a low risk propensity. ${ }^{37}$ These stereotypical characteristics, if true, make engineers poorly trained 
for entrepreneurial situations which involve risk and uncertainty. Courses teaching entrepreneurship must then place the engineering students in situations where they solve problems under conditions of ambiguity and risk.

- Integration of business fundamentals: All entrepreneurs must have a sense of knowledge concerning the fundamentals of business. Hal Kamine stated in a recent lecture at Lafayette College that one of the best courses he took at Lafayette was Engineering Economics, a course addressing the value of money and various ways of financing projects. ${ }^{38}$ With a requirement of courses such as this in the curricula, students will be better prepared for the real world, armed with the knowledge of both technology and the financing and marketability of the technology.

- Upper-Level Design Courses which combine the technological innovations of engineering with the tools and analytical techniques of entrepreneurship: Upper-level labs can be created across the engineering disciplines which require students, in addition to designing products, to develop business plans and marketing strategies for the products. Grading would then be determined not only on the quality of design of the product, but also on the viability of the business plan.

- Engineering Entrepreneurial Society: Currently, Lafayette College offers an entrepreneurial society to students known as the CIRCLE Entrepreneurship club. This entrepreneurial society targets mainly business and economics students and has the main purpose of organizing entrepreneurial lectures for its members. The creation of an additional entrepreneurial society which focused mainly on engineering and technological entrepreneurship would allow engineering students the opportunity to enhance their entrepreneurial education beyond the classroom while addressing the topics more pertinent to these students' interests.

- $\quad$ Practicing Entrepreneurs as guest lecturers: Already in the Fall of 2006, Hal Kamine has visited Lafayette College twice to lecture engineering students, with a warm reception at both lectures. James Fisher also returned in the Fall of 2006 to a full auditorium to provide his experiences and advice in entrepreneurship. The large attendance at these lectures indicates the interest of students in entrepreneurship, and the advice provided by practicing entrepreneurs will be more valuable to students than additional readings or structured coursework. 


\section{Glossary}

Behaviorists - A group of individuals studying human behavior and includes psychologists, psychoanalysts, and sociologists.

Commercialization - The process of developing marketable products or services and producing and delivering products or services for sale to government or commercial markets

Competencies - Is more than just skill and knowledge, involves the ability to meet complex demands, by drawing on and mobilizing psychosocial resources in a particular context

Competitive Globalization - The concept that the global economy ha a greater influence on the US economy than the government

Creative Economy - The concept that the US economy is becoming more individualized and customized as the amount of information available is increasing due to the increases in innovative technological advancements

Creative Thinking - The ability to think of original, diverse, and elaborate ideas.

Critical Thinking - The intellectually disciplined process of actively and skillfully conceptualizing, applying, analyzing, synthesizing, and/or evaluating information gathered from, or generated by, observation, experience, reflection, reasoning, or communication, as a guide to belief and action

Entrepreneurship - Innovation; the process of starting or growing a business or venture

Entrepreneurship Education - Programs, schools, and other ways to inform potential entrepreneurs about the tools necessary for a successful small business

Leadership - "The only definition of a leader is someone who has followers",39

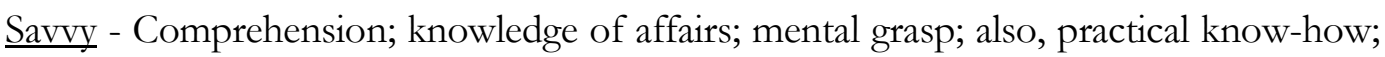
common sense 
${ }^{1}$ Bordogna, J. (2003). Importance of Entrepreneurs to the US Economy. Proceedings from ECI 2003: Conference on Teaching Entrepreneurship to Engineering Students, Monterey, CA. p.2

${ }^{2}$ The Public Forum Institute. (2006). National Dialogue on Entrepreneurship. Retrieved

November 13, 2006 from http://www.publicforuminstitute.org/nde/aboutnde/index.htm

${ }^{3}$ Bordogna, p. 1

${ }^{4}$ Suhir, E. (2005). Inventive Leadership: Can a Good Engineer become a Successful

Entrepreneur? Mechanical Engineering Magazine. Retrieved October 1, 2006 from http://www.memagazine.org/contents/current/webonly/wex110205.html

${ }^{5}$ Kauffman Foundation. (2006). Collegiate Entrepreneurship Resource Center. Retrieved

September 1, 2006 from

http://www.kauffman.org/campuses/?CFID=2998988\&CFTOKEN=28370841

${ }^{6}$ Lafayette College Website. (2006). http://www.lafayette.edu

${ }^{7}$ McDaniel, B. (2002). Entrepreneurship and Innovation: An Economic Approach. Armonk, NY:

M.E. Sharpe, Inc. p. 31

${ }^{8}$ McDaniel, p.32

${ }^{9}$ McDaniel, p.32

${ }^{10}$ McDaniel, p.31

${ }^{11}$ McDaniel, p.32-33

${ }^{12}$ Kauffman Foundation

${ }^{13}$ Edmondson, M. (2006). Idea Validation and Opportunity Assessment in the Creative Economy. Invention to Venture Workshop, Rowan University, Glassboro, NJ.

${ }^{14}$ Edmondson, $\mathrm{M}$.

${ }^{15}$ Baron R. and Shane, S. (2005). Entrepreneurship: A Process Perspective. Mason, OH: SouthWestern. p.28

${ }^{16}$ Baron and Shane, p.28

${ }^{17}$ Bullvaag, E. Acs, Z. Allen, I.E. Bygrave, W.D. and Spinelli, S. (2005). 2004-2005 Executive Report. Global Entrepreneurship Monitor. MA: Babson College, USA: George Mason School of Public Policy. p. 26

${ }^{18}$ Bullvaag et al, p. 10

${ }^{19}$ Bullvaag et al, p.10

${ }^{20}$ Kaplan, J. (2003). Patterns of Entrepreneurship. New York, NY: John Wiley \& Sons, Inc. p.4

${ }^{21}$ Bullvaag et al, p.10

${ }^{22}$ Bullvaag et al, p.10

${ }^{23}$ Filion, L. (2006). From Entrepreneurship to Entreprenology. United States Association for Small Business and Entrepreneurship. Retrieved October 1, 2006 from http://www.usasbe.org/knowledge/proceedings/1997/P207Filion.PDF I1

${ }^{24}$ Mars, M. (2006). The Emerging Domains of Entrepreneurship Education: Students, Faculty, and the Capitalist Academy. Submitted at The University of Arizona in partial fulfillment of degree of PhD. p. 16

${ }^{25}$ Filion, II4

${ }^{26}$ Crainer, S. (1998). The Ultimate Book of Business Gurus: 110 Thinkers who Really Made a Difference. New York, NY: AMACOM. p.193

${ }^{27}$ Crainer, p.192-193

${ }^{28}$ Crainer, p.50-54

${ }^{29}$ Filion, $\mathbb{\text { II }}$

${ }^{30}$ Filion, II 1

${ }^{31}$ St. John, C. (2003). Attributes of Entrepreneurs: Personality versus Perspective. Proceedings from ECI 2003: Conference on Teaching Entrepreneurship to Engineering Students, Monterey, CA. p.6

${ }^{32}$ Pendergast, W. (2003). Entrepreneurial Contexts and Traits of Entrepreneurs. Proceedings from ECI 2003: Conference on Teaching Entrepreneurship to Engineering Students, Monterey, CA. p.1

${ }^{33}$ St. John, p.11

${ }^{34}$ Pendergast, p. 3

${ }^{35}$ McDaniel, p.68 
${ }^{36}$ Hjorth, D. (2003). Rewriting Entrepreneurship. Sweden: Wallin \& Dalholm Boktryckeri AB. p. 158

${ }^{37}$ Crockett, R. (2003). Reaching Out to Entrepreneurial Engineers. Proceedings from ECI 2003: Conference on Teaching Entrepreneurship to Engineering Students, Monterey, CA. p.5

${ }^{38}$ Kamine, H. (2006). Engineering and Entrepreneurship. Resnik Lecture, Lafayette College, Easton, PA.

${ }^{39}$ Hesselbein, F. Goldsmith, M. \& Beckhard, R. (1996). The Leader of the Future. San Francisco, CA: Jossey-Bass. p.xi 